\title{
Žensko sodišče: feministični model pravičnosti
}

Institucionalni pravni sistem pogosto retravmatizira ženske, ki pričajo o preživetih vojnih grozotah, smrti bližnjih oseb, pregonu z domov, posilstvih. Preživeto nasilje je pomembno le kot dokaz v kazenskih postopkih, priče na sodišču so izpostavljene in osamljene. Da bi se ženske organizacije medsebojno povezale in podprle ter presegle omenjeno instrumentalizacijo preživetih izkušenj, so na lokalni, regionalni in mednarodni ravni razvile ženska sodišča, ki so simbolne instance, $\mathrm{v}$ katerih prevladuje feministični model pravičnosti in skrbi. To so sodišča, ki ustvarjajo skupnosti alternativnega kolektivnega spomina. Ženska sodišča so varni prostori, kjer ženske pričajo o izkušnjah nasilja v času vojne in kjer javno poimenujejo zločine, da bi se na simbolni način kaznovalo storilce in bi se vzpostavil sistem pravičnosti. Ti prostori so izraz odpora in razvijanja skupnosti podpore, medsebojnega razumevanja, spoštovanja; $v$ njih se izražajo kolektivne zahteve po pravičnosti.

Prvo žensko sodišče je bilo organizirano leta 1992 v Lahoreju v Pakistanu (Kovačević, Perković in Zajović, 2011). Na Fakulteti za socialno delo smo 25. februarja 2020 imeli priložnost in čast poslušati glasove preživelih (boljši izraz kot »žrtev«) vojnih in povojnih zločinov na prostoru nekdanje Jugoslavije, ki so pričale med 7. in 10. majem 2015 v Sarajevu, na prvem evropskem ženskem sodišču. V okviru njegovega delovanja je pričalo 36 žensk iz nekdanje Jugoslavije, njihove zgodbe je poslušalo 500 udeleženk. Ta »zgodovinski avditorij« (Zajović in Urošević, 2017) so med drugim sestavljale predstavnice ženskih organizacij iz mnogih držav sveta, ki pripadajo mreži ženske solidarnosti. Na dogodku, ki je potekal na Fakulteti za socialno delo, smo med drugim slišali Stašo Zajović iz srbske organizacije Ženske v črnem, prav ona je tudi organizirala priprave na žensko sodišče v Sarajevu. Zajović je njegov največji pomen videla v tem, da so priče v času priprav spremenile percepcijo »sebe«. Z drugimi besedami premagale so osamljenost, prekinile tišino in od pasivnih žrtev postale subjekti, ki zahtevajo pravično obravnavo storilcev in žrtev/preživelih.

Žensko sodišče v Sarajevu je osvetlilo različne vidike nasilja nad ženskami $v$ času vojne na območju Jugoslavije v devetdesetih letih 20. stoletja in po njej. Med drugim je obravnavalo vojno proti civilnemu prebivalstvu, spolno nasilje v vojni, vojaško nasilje in odpor žensk proti njemu, pregon »drugačnih« v vojni in miru (etnično nasilje), socialno-ekonomske zločine nad ženskami in njihov odpor (Žene u crnom, 2016).

Na Fakulteti za socialno delo smo 25. februarja 2020 poslušali zgodbe štirih žensk, ki so pripovedovale o izkušnjah spolnega, vojaškega in ekonomskega 
nasilja ter o izkušnjah terorja, ki se je zgodil izbrisanim (poimenovanje za ljudi, ki so jih upravni organi Republike Slovenije kmalu po osamosvojitvi Slovenije izbrisali iz registra stalnega prebivalstva, brez pravne podlage). V njihovih pripovedih smo lahko slišali, kako se omenjene oblike nasilja med seboj prepletajo in krepijo. Ženske zgodbe, zaznamovane z izgubami, so poslušalstvo, največ je bilo študentk in študentov socialnega dela in družboslovnih predavateljic in profesoric, ganile z neizmernim pogumom za pričevanje, močjo preživetja, z resnico in močjo povezanosti. Gostje so prišle iz različnih držav nekdanje Jugoslavije, še ena specifičnost iniciative ženskega sodišča. Ženske so bile po delih Jugoslavije, kjer je divjala vojna, v podobnem položaju. Nekatere so pretrpele najhujše vojne posledice, saj so živele na etničnih območjih, ki so bila napadena in kjer se je dogajalo etnično čiščenje, predvsem v Bosni in Hercegovini, na Kosovem in Hrvaškem. Druge so izhajale iz držav, ki so vojno dejavno organizirale: iz Srbije, Črne gore in delno Hrvaške. Kljub temu je skupna izkušnja vseh žensk, da so plačale najvišjo ceno vojne, militarizma in nacionalizma (Zajović in Urošević, 2017).

Ženske imajo namreč v kontekstu vojaškega nacionalizma posebno vlogo. Omenjeni koncept reproducira etnične meje ter delitev na »mi« in »oni«. Znotraj teh meja je ženski dodeljena vloga zaščitnice nemočnih in »matere nacije«, zato je odgovorna za biološko reprodukcijo »naših otrok«. Ženska je potemtakem v vojaškem nacionalizmu objekt, orožje in tehnika, ki se jo uporablja v vojnah za premagovanje nasprotnika, konstruiranega »drugega«.

Kot trdi Morokvasic (2002, str. 70-73), so bili dominacija, ponižanje, premoč in uničenje »drugega «, o vsem tem so pripovedovale ženske iz prostorov nekdanje Jugoslavije, izvajani z uporabo ženskega telesa. Sovraštvo in nasilje se je izkristaliziralo $\mathrm{v}$ dejanjih posilstev, ki so postala orodje vojne, da bi osvajalec z njim dokončno uničil in ponižal tistega, ki ga želi osvojiti. Obravnavanje posilstva samo kot zločina nad etnično skupnostjo zasenči dejstvo, da so ženske posiljene, ker so hkrati »druge ženske« in »etnično druge«. Zato je v dokumentarnem filmu Ženski sud - feministični pristup pravdi (Žensko sodišče - feministični pristop k vprašanju pravičnosti), ki smo si ga ogledali med dogodkom, kategorizacija spolnega nasilja uporabljena v kontekstu »ženskega telesa kot bojišča« (Žene u crnom, 2016).

Članice Organizacijskega odbora ženskega sodišča (Staša Zajović, Nela Pamuković, Marijana Senjak), priče z ženskega sodišča v Sarajevu (Mirjana Učakar, Milica Miladinović, Suvada Selimović, Marica Šeatović) in organizatorka dogodka na Fakulteti za socialno delo (Jelka Zorn) so med dogodkom pripovedovale o pomenu ženskih sodišč, ki je v pričanju, uporništvu in prizadevanju, da glasovi, ki so bili toliko časa utišani in marginalizirani, postanejo slišani ter postanejo del zgodovinskega in kolektivnega spomina. S pričevanjem žensk na ženskih sodiščih se razvija solidarnost, zaradi pripovedovanja postanejo zgodbe slišane. Šele tako dobijo pretekle izkušnje javno vrednost in omogočijo osebne spomine.

Dogodek na Fakulteti za socialno delo je študentkam in študentom prikazal, kaj pomeni boj za pravičnost, za to, da si vzamemo prostor in poslušamo 
druga drugo, kaj pomeni pogum za to, da govorimo in smo priče druga drugi, kaj pomenijo medsebojno sodelovanje, solidarnost in podpora znotraj konteksta nacionalizma, ki sovraštvo do »drugega « normalizira. Ženske so tako premostile sovraštvo, ki ga podžigajo vojne in nacionalizem, dosegle pa so tudi, da so se njihovi glasovi zapisali v zgodovino, kljub mnogim izgubam in hudi bolečini ob pripovedovanju zgodb. Šaha Hrustić v omenjen dokumentarnem filmu (Žene u crnom, 2016) pravi:

Boj je tudi to, da prenesemo naše znanje, saj je znanje nekakšna zgodovina, prava zgodovina. Da nam nihče ne izkrivi slike [...]. Pripovedujmo resnico!

Tudi sama sem študentka socialnega dela in menim, da se stroka in znanost socialnega dela lahko veliko naučita iz prakse ženskih sodišč. Ženskih pričam se moramo zahvaliti za to, da na mlajše generacije prenašajo spomin na svoje izkušnje.

\section{Viri}

Kovačević, L., Perković, M., \& Zajović, S. (2011). Ženski sud: feministički pristup pravdi. Novi Sad: Artprint.

Morokvasic, M. (2002). The logics of exclusion: nationalism, sexism and the Yugoslav war. V N. Charles, \& H. Hintjens (ur.), Gender, ethnicity and political ideologies (str. 66-90). London: Routledge.

Zajović, S., \& Urošević, M. (2017). Ženski sud: o događaju u Sarajevu i o nastavku procesa. Novi Sad: Artprint.

Žene u crnom (2016). Ženski sud - feministički pristup pravdi [Video]. Pridobljeno 25. 8. 2020 s https://www.youtube.com/watch?v=q62YLeMm1yU\&t=596s 
